\title{
GENETIC AND SELECTION ASSESSMENT OF THE SCOTS PINE (PINUS SYLVESTRIS L.) IN FOREST SEED ORCHARDS
}

\author{
Elvira Khanova, Vladimir Konovalov, Azat Timeryanov \\ Regina Isyanyulova, Dina Rafikova \\ Bashirir State Agrarian University \\ Ufa, Russia \\ (Received August 20I9)
}

\begin{abstract}
Cultivation of highly productive stands of the Scots pine is a priority task of the forestry industry. This task should be solved using the methods based on the molecular genetic analysis. Following these methods carefully will allow improving the work quality and efficiency in the forest seed farming, to control successfully the stand phytosanitary condition, as well as to use DNA markers in the in vitro culture reproduction of tree species. Our studies have shown a high level of the Scots pine genetic diversity in forest seed orchards, which is confirmed by insignificant spread of values between similar studied characteristics when analyzing the Scots pine with high morphological characteristics, selected from natural populations. Thus, genetic monitoring of the objects of permanent forest seed base of this tree species should be introduced into practice of the forest selection seed farming.
\end{abstract}

KEYWORDS: Gene resources, forest seed orchards, clone, plus tree, stand origin, genetic markers.

\section{INTRODUCTION}

An urgent problem of the forest seed selection farming is the search for effective measures to preserve the gene of valuable forest-forming tree species (Ivanovskaia 2004, Tsarev 2013, Vidiakin 2003), especially coniferous ones (Tsarev 2006, Vidiakin 2008).

Forest seed farming involves a number of measures to create a forest seed base on the selection and genetic basis for cultivation of highly productive and sustainable forest stands (Redko et al. 2008).

The work under Federal Target Program "Development of forest seed selection farming for the period 2009-2020" (The Federal Target Program of the Forest Seed Production development 
for the period from 2009 to 2020 2009) resulted in entity generation of a high quality unified genetic and selection complex of, including forest seed orchards (FSO), created by using vegetative and seed material of plus and elite trees. Therefore, one of the priority areas is the study and assessment of the selected plus forest gene, and proposals for further forest seed farming development (Besschetnov and Besschetnova 2012, Ivanovskaia 2014, Vidiakin 2010).

The most important condition for maintaining forest ecosystems resistance to external forcing (climatic, anthropogenic) is the conservation and reproduction of biodiversity (Gabdrakhimov et al. 2015, Sultanova et al. 2018). Special attention in solving this problem should be paid to the study of the intraspecific and genetic potential of the main forest-forming species of woody plants, the Scots pine (Pinus sylvestris) being one of them (Prishnivskaia et al. 2016). The ability of a population to adapt to extreme environmental conditions in the process of natural selection depends on its genetic diversity. At low rates of intrapopulation polymorphism, the number of possible combinations of genes promoting adaptation to the environment decreases, which reduces the possibility of new adapted genotypes to occur in this population (Copenheaver et al. 2002, Wieser et al. 2018). Thus, the population in natural conditions should have an appropriate level of genetic diversity to be able to survive under the pressure of constantly changing biotic and abiotic components of the ecosystem (Grushetskaia et al. 2013).

The problem of the genetic diversity conservation should not be disregarded when implementing tree species breeding programs. During different selection cycles phenotypic selection and production of seeds and seedlings should be done very carefully (El-Kassaby 1995). Otherwise, at the stage of phenotypic selection the level of genetic diversity can be reduced.

Genetic diversity defines the ability of living organisms to adapt to environmental changes and determines the variability of their features and properties.

However, different kinds of variance are not sufficiently used in economic activities, which may finally lead to the genetic potential constriction of forest seed objects. Thus, making correct selection and characterization of genetic resources are the main tasks in modern woody plants selection (Shigapova and Shigapov 2009, Swamy et al. 2018).

Use of the Ex Situ method can help to preserve the forest species genetic diversity (Feng et al. 2006). Clone and seed plantations are the center of the conservation of forest genetic resources, as the relationship between the population size and the percentage of the retained heterozygosity are reduced to a minimum loss of the total additive genetic variance. Kajba (Kajba and Andric 2019) notes that in Croatia they have started the works on the phenotypic selection and vegetative reproduction of plus trees. In addition, in order to produce forest seeds of high genetic quality, the creation of clone plantations has been started. That was the beginning of the genetic assessment of mother trees and of genotypic selection in order to obtain higher genetic growth.

$\mathrm{Up}$ to the present moment, most researches on the Scots pine genetic variance have been aimed to study the growth (DeSiervo et al. 2018), morphological characteristics (Copenheaver et al. 2002, Seo et al. 2013) and plantability of this species (Porth and El-Kassaby 2014). The studies of genetic variance are mainly concentrated on the isoenzymes analysis. Some articles describe species variance at the DNA level, as well as of the variance of the genes encoding ribosomal units. Outstanding features of the DNA analysis technology are its high informative value, no need for genome pre-sequencing to develop primers, possible primers universality for different species, and relatively low cost. The ISSR technology is considered to be reliable due to the use of longer primers (Nkongolo et al. 2002).

Reliability of the phenotypic evaluation of the genotype in forest selection research works is most commonly identified with the assessment of genetic polymorphism. Evaluation of genetic polymorphism is becoming more common in the forest breeding science. Genetic variance helps 
to determine the resistance of forest stands to environmental conditions. It is also a source of information for the improvement of breeding programs (Zheng et al. 2015).

The method of studying forest seed farming includes the work on valuable tree species breeding, their accounting and gene resource analysis. Relaxation of the forest stands gene resource is primarily associated with such phenomena as inbreeding and reduction of climax forest with representative genes bank. As a whole, all this can lead to a decrease in the stands resistance to environmental conditions and to human impact.

With reference to the above mentioned, the issue of natural gene resource conservation in order to enhance breeding properties of tree species is becoming a priority in the research in the field of genetics and selection of woody plants.

The aim of the study was to determine the genetic variance of the Scots pine clones at the sites of a unified genetic-breeding complex, including forest seed orchards (FSO). For this purpose, the following tasks were set and successfully solved: one-site investigation of FSO and definition of their main mensurational indicators; collection of needles from the Scots pine clones for further genetic analysis and DNA isolation; polymerase chain reaction with the use of five ISSR primers; electrophoretic separation of polymerase chain reaction products (PCR); data analysis and development of recommendations.

\section{MATERIALS AND METHODS}

\section{Research object.}

The research was conducted in forest seed orchards of vegetative origin (1980-1989), located in Angasiaksk forest division of the Diurtiuli district forestry of the Republic of Bashkortostan.

\section{Data collection and analysis.}

The research was based on the sample plot method. All sample plots were laid and processed by general forest inventory methods. The data were processed by the methods of variation statistics and with the use of the Statistica 6 software package. For laboratory research on the scientific problem to be developed, source material was selected by the recommended CTAB method (Cetyl Trimethyl Ammonium Bromidium) (El-Kassaby 1995). Fresh needles of the Scots pine from seed plantations were used as a source material for genetic studies.

While studying seed production patterns of the Scots pine clones we carried out the works on the phenological observation of the process. Seed production level was assessed according to three phases: early flowering of reproductive organs, seed-bud early formation and conelet early formation inside the clone.

Tab. 1 presents a brief description of five ISSR primers which were used to isolate DNA from needles.

Tab. 1: Characteristics of the used ISSR-primers.

\begin{tabular}{|c|l|c|}
\hline No. & \multicolumn{1}{|c|}{ Primer } & Sequence (5-3) \\
\hline 1 & $(\mathrm{CA})_{6} \mathrm{AGCT}$ & CACACACACACAAGCT \\
\hline 2 & $\left(\mathrm{CA}{ }_{6} \mathrm{AG}\right.$ & CACACACACACAAGG \\
\hline 3 & $(\mathrm{CA})_{6} \mathrm{GT}$ & CACACACACACAGT \\
\hline 4 & $(\mathrm{CA})_{6} \mathrm{AS}$ & CACACACACACAAC \\
\hline 5 & $(\mathrm{AG})_{8} \mathrm{~T}$ & AGAGAGAGAGAGAGAGT \\
\hline
\end{tabular}


The experimental part of the study on the polymerase chain reaction evaluation was carried out using test tubes with the MJ Mini TM Gradient Thermal Cycler (BIO-RAD) amplifier. The recommended Encyclo PCR reagents kit was used for the experiments.

Basic requirements met at the laboratory research stage were as follow: the reaction mixture of $10 \mu \mathrm{l}$ contained $1 \mu \mathrm{l}$ of PCR buffer; $0.2 \mu 1$ of $10 \mathrm{Mm}$ dNTPs; $0.1 \mu 1$ of $100 \mu \mathrm{m}$ of primer; $1 \mu \mathrm{l}$ of DNA sample; $0.1 \mu \mathrm{l}$ of Taq polymerase $(2 \mathrm{u} / \mu \mathrm{l}) ; 7.6 \mu \mathrm{l}$ of water. The following amplification regime was chosen: 5 min denaturation at $94^{\circ} \mathrm{C} ; 0.5$ min denaturation at $94^{\circ} \mathrm{C} ; 45 \mathrm{sec}$ annealing $\left(45-60^{\circ} \mathrm{C}\right) ; 2$ min elongation at $72^{\circ} \mathrm{C} ; 7$ min extension at $72^{\circ} \mathrm{C}$. The entire amplification process consisted of 45 successive cycles.

Later the separation of PCR products was carried out. It was carried out during 45-60 min in a horizontal electrophoretic chamber (Power PacTM Universal (BIO-RAD)) using $1.5 \%$ agarose gel and adding ethidium bromide at a voltage of $70 \mathrm{mV}$. DNA 100+DNALadder length mark was laid out in the farthest track. TVE buffer in the form of a complex mixture was used for electrophoresis: tris- $\mathrm{HCl}(\mathrm{pH}=8.3)-12.1 \mathrm{~g}$; boric acid - $5.1 \mathrm{~g}$; EDTA (sodium salt) $-0.37 \mathrm{~g}$; distilled water $-1000 \mathrm{ml}$.

DNA visualization, processing and analysis of the obtained images were performed using GelDoc 2000 (BIO-RAD) gel-documentation system and Quantity One ${ }^{\circledR}$ Version 4.6.3 software package.

Popgene Version 1.32 program was used to calculate genetic parameters of the Scots pine trees. The program determines the proportion of polymorphic loci, the total (observed) number of alleles (na), the effective number of alleles (ne), Ney genetic diversity $(\mathrm{N})$, the proportion of interpopulation genetic diversity in the total diversity, or the population subdivision index (Gst). Having analyzed the electrophoregrams, a binary matrix was compiled. "1" was the symbol to mark the present PCR fragments of the matrix and "0"- for the missing ones.

\section{RESULTS}

The studied stands of the Scots pine proved to be high-bonitat plantings clean in composition. The main forest inventory indicators of the stands are presented in Tab. 2.

Tab. 2: Biometric indicators of the Scots pine seed plantations.

\begin{tabular}{|c|c|c|c|c|c|}
\hline Indicators & M & $\pm \mathrm{m}$ & $\sigma$ & $\mathrm{V}, \%$ & $\mathrm{P}, \%$ \\
\hline \multicolumn{6}{|c|}{ FSP (Forest Seed Plantation) No. 32} \\
\hline Trunk diameter, $\mathrm{cm}$ & 25.01 & 1.21 & 4.86 & 19.43 & 4.84 \\
\hline Bole height, $\mathrm{m}$ & 14.98 & 0.64 & 2.70 & 18.02 & 4.27 \\
\hline Crown width, $\mathrm{m}$ & 6.62 & 0.30 & 1.80 & 27.19 & 4.53 \\
\hline Crown length, $\mathrm{m}$ & 13.01 & 0.62 & 5.50 & 42.28 & 4.77 \\
\hline \multicolumn{6}{|l|}{ FSP No. 18} \\
\hline Trunk diameter, $\mathrm{cm}$ & 27.79 & 1.88 & 4.52 & 16.26 & 6.77 \\
\hline Bole height, $\mathrm{m}$ & 17.14 & 0.82 & 3.10 & 18.09 & 4.78 \\
\hline Crown width, $\mathrm{m}$ & 8.04 & 0.58 & 1.90 & 23.63 & 7.21 \\
\hline Crown length, $\mathrm{m}$ & 14.24 & 0.90 & 6.30 & 44.24 & 6.32 \\
\hline \multicolumn{6}{|l|}{ FSP No. 24} \\
\hline Trunk diameter, $\mathrm{cm}$ & 32.33 & 1.94 & 4.76 & 14.72 & 6.00 \\
\hline Bole height, $\mathrm{m}$ & 13.50 & 0.92 & 2.26 & 16.74 & 6.81 \\
\hline
\end{tabular}




\begin{tabular}{|l|r|r|r|r|c|}
\hline Crown width, m & 10.25 & 0.78 & 1.92 & 18.73 & 7.61 \\
\hline Crown length, m & 10.67 & 0.72 & 7.10 & 66.54 & 6.75 \\
\hline FSP No. 28 & 37.42 & 1.59 & 3.90 & 10.42 & 4.25 \\
\hline Trunk diameter, cm & 12.75 & 0.57 & 1.41 & 11.06 & 4.47 \\
\hline Bole height, m & 9.83 & 0.40 & 0.99 & 10.07 & 4.07 \\
\hline Crown width, m & 12.31 & 0.89 & 5.90 & 47.93 & 7.23 \\
\hline Crown length, m
\end{tabular}

The main indicators of the Scots pine stands in forest seed plantations are characterized by high features variability under identical growth conditions. The height variability coefficient within clones varies from $11.06 \%$ to $18.09 \%$, the diameter coefficient from $10.42 \%$ to $19.43 \%$, the crown diameter from $10.07 \%$ to $27.19 \%$, the crown length variability coefficient varies from of $42.28 \%$ to $66.54 \%$. The studied stands are generally characterized by a good trunk state and crown development.

During the phenological observation it was noted that the studied clones of the Scots pine growing in the forest seed orchard No. 32 of vegetative origin are characterized by a high rate of seed-bud and conelet formation. The main morphometric features of conelets are given in Tab. 3.

Tab. 3: Main indicators of the Scots pine conelets.

\begin{tabular}{|l|c|c|c|c|c|}
\hline \multirow{2}{*}{$\begin{array}{c}\text { Characteristics } \\
\text { to be measured }\end{array}$} & \multicolumn{5}{|c|}{ Average statistical values } \\
\cline { 2 - 6 } & $\mathrm{M}$ & $\pm \mathrm{m}$ & $\sigma$ & $\mathrm{V}(\%)$ & $\mathrm{P}(\%)$ \\
\hline Length, cm & 5.1 & 0.1 & 1.02 & 20.0 & 2.0 \\
\hline Diameter, cm. & 3.5 & 0.11 & 0.65 & 13.3 & 2.2 \\
\hline Weight, g & 16.4 & 0.68 & 4.22 & 25.7 & 4.1 \\
\hline
\end{tabular}

The greatest variability is characteristic for the conelets weighing $(\mathrm{V}=25.7 \%)$. The conelets length and width are more stable ( $V=20,0 \%$ and $13,3 \%$ respectively). When the variability values of the conelets linear indicators are low, their weight ranges greatly. This is due to a large amount of empty and germless seeds inside the conelets.

According to the results of the ISSR-analysis of DNA isolated from the Scots pine needles, the following results were obtained: 96 amplified fragments were identified when using five ISSR primers. 20 of these 96 fragments are accounted for (CA) 6AGCT and (CA) 6GT, 23 - for (CA) $6 \mathrm{AG}, 18$ - for (CA)6 AS, 15 - for (AG) 8T. The results of DNA analysis of the Scots pine are shown in Tab. 4.

Tab. 4: Results of PCR analysis of the Scots pine trees DNA.

\begin{tabular}{|l|c|c|c|}
\hline \multirow{2}{*}{ Primer } & \multicolumn{2}{|c|}{ The number of DNA fragments } & Amplified fragments \\
\cline { 2 - 3 } & Totally & polymorphic & size \\
\hline$(\mathrm{SA}){ }_{6} \mathrm{AGCT}$ & 20 & 16 & $230-1220$ \\
\hline$(\mathrm{CA}){ }_{6} \mathrm{AG}$ & 23 & 20 & $200-1270$ \\
\hline$(\mathrm{CA})_{6} \mathrm{GT}$ & 20 & 17 & $260-1240$ \\
\hline$(\mathrm{CA}){ }_{6} \mathrm{AS}$ & 18 & 14 & $230-1700$ \\
\hline$(\mathrm{AG}){ }_{8} \mathrm{~T}$ & 15 & 12 & $290-1200$ \\
\hline Totally & 96 & 79 & $200-1700$ \\
\hline
\end{tabular}


The share of polymorphic loci varied from 12 to 20 DNA fragments. 96 DNA fragments were isolated in total, 79 of them being polymorphic ones. The variability in the size of DNA fragments ranged from 200 to 1700 nucleotide pairs.

According to the results of the analysis and estimation of the clones' genetic variability conducted on the FSP to be studied, we managed to establish the occurrence frequency of alleles of the detected loci. It was found that the effective number of alleles $(\mathrm{Ne})$ on the studied seed plantations was 1.385 . The total genetic diversity $(\mathrm{H})$ amounted to 0.239 .

\section{DISCUSSION}

At present, the method of molecular genetic analysis is increasingly used to identify the most valuable forest plantations in regard to genetics, to identify individual forms of tree species with high trunk quality, growth rate and other valuable features. This method allows estimating the level of genetic diversity in natural populations and its possible losses during artificial reforestation (Tsarev 2006). It also helps to identify populations from different geographical regions, to determine the level of stands inbreeding, to appreciate genetic quality of their seeds (Sheikina 2014), as well as to identify plants resistant to pathogens and various pollutants (Feng et al. 2006, Hui-yu et al. 2005, Sultanova et al. 2018). The purpose of the practical application of molecular genetic analysis is not only to assess the genetic resources state of, but also to develop a strategy for the genetic diversity conservation of an appropriate species (DeSiervo et al. 2018, Provan et al. 1998).

According to (Ivanovskaia 2014), a reliable parameter characterizing the level of genetic variability of indicators of the tree species population is average heterozygosity which can be observed $\mathrm{Ho}$ (actual) and expected $\mathrm{He}$ (calculated from allele frequencies). It is important to take into account the size of the samples of the studied tree species. They should be representative, which will ensure high accuracy of calculating the average value of the observed and expected heterozygosity.

When assessing the level of genetic variability of the Scots pine phenotypic characteristics, we paid attention to research articles of scientists dealing with this problem. Thus, in the studies of (Novikov and Sheikina 2012) the value of the average expected heterozygosity He in plus Scots pine stands was 0.273 . According to the studies of Ivanovskaya S. I., the same value was equal to 0.250 (Ivanovskaia 2014). In the work of Nowakowska J. this parameter was 0.289 (Nowakowska et al. 2014). Comparative data on the levels of genetic variability of the Scots pine trees on forest seed sites are given in Tab. 5 .

Tab. 5: Main indicators of genetic variability.

\begin{tabular}{|l|c|c|c|c|}
\hline Indicators of genetic variability & Research data & $\begin{array}{c}\text { Novikov, Sheikina } \\
(2012)\end{array}$ & $\begin{array}{c}\text { Ivanovskaia } \\
(2014)\end{array}$ & $\begin{array}{c}\text { Nowakowska } \\
(2014)\end{array}$ \\
\hline Share of polymorphic loci (P,\%) & 82 & 94 & 85 & 84 \\
\hline Expected heterozygosity (He) & 0.239 & 0.273 & 0.250 & 0.289 \\
\hline
\end{tabular}

Thus, the results of the study prove a high level of genetic diversity and variability of stands of the Scots pine on the studied seed plantations created by vegetative material. This fact is confirmed by slight differences between the final data of our studies and the data of other scientists (Tab. 5). It should be noted that the level of genetic variability of trees on forest seed sites is not inferior to the level of genetic variability detected in Italy $(\mathrm{He}=0.347$ ) (Copenheaver 
et al. 2002), Romania and Sweden $(\mathrm{He}=0.297)$ (Floran et al. 2010), Finland $(\mathrm{He}=0,312)(\mathrm{Zheng}$ et al. 2015), Scotland and Spain ( $\mathrm{He}=0,297)$ (Provan et al. 1998).

The most important condition for obtaining genetic diversity of tree species is the presence on the forest seed plantations of such number of unlike clones as necessary to ensure a high level of genetic variability (Feng et al. 2006, Kajba and Andric 2019, Seo et al. 2013). Average values of heterozygosity of the Scots pine grown on forest seed plantations differ significantly from the same values of this species grown in natural populations (Floran et al. 2010, Nowakowska et al. 2014).

According to Wójkiewicz et. al (2016), a better understanding of the formation of the Scots pine population is important in developing programs to conserve the species genetic resources as well as evaluating the role of natural selection across the species' range.

The Scots pine is characterized by a high level of population genetic diversity and a low divergence degree within the species in the studied part of the area (Raj et al. 2006, Wieser et al. 2018). Seo et al. (2013) in his studies gives the analysis to the nature of rare alleles spacing and of the distribution of intraspecific genetic diversification, which is illustrative of relative gene resources throughout the species range. The Scots pine populations exchange genetic material to support the genetic basis of the species as a whole (Nkongolo et al. 2002). The results of our research on the PCR analysis of the Scots pine trees DNA are confirmed by Hui-yu (Hui-yu et al. 2005).

Authors proved great importance of molecular genetic analysis when studying gene resources of populations (Copenheaver et al. 2002, Feng et al. 2006, Kajba and Andric 2019). Based on these studies, it is possible to determine the main characteristics of the main forest-forming species.

Z. Hong, M. R. G Gil note that studies which are based on the genetic approach will allow to understand the essence of the influence of natural selection on the genomic patterns of forest tree species, to gain new knowledge about the evolutionary processes that affect the nature of pine genetic variability.

\section{CONCLUSIONS}

Molecular genetic analysis with the use of ISSR-markers allowed us to obtain new data on the gene resources state of the Scots pine on forest seed plantations of the Republic of Bashkortostan. On the basis of our studies we revealed that the effective number of alleles $(\mathrm{Ne})$ on the studied seed plantations was 1.385 . The total genetic diversity $(\mathrm{H})$ amounted to 0.239 . The share of polymorphic loci varied from 12 to 20 DNA fragments. 96 DNA fragments were isolated in total, 79 of them being polymorphic ones.

The results of our research prove a high degree of genetic variability of the Scots pine clones, which suggests that vegetative material for seed plantations was chosen properly. Continuous monitoring of forest seed objects at genetic and breeding level is necessary in order to conserve high-quality gene resources of the Scots pine tree species. When creating new objects of a unified genetic and breeding complex, it is necessary to provide intensive control on the quality and genetic diversity of the planting material. 


\section{REFERENCES}

1. Belletti, P., Ferrazzini, D., Piotti, A., Monteleone, I., Ducci, F., 2012: Genetic variation and divergence in Scots pine (Pinus sylvestris L.) within its natural range in Italy. European Journal of Forest Research 131(4): 1127-1138.

2. Besschetnov, V., Besschetnova, N., 2012: Complex assessment of the Scots pine plus trees according to their needles parameters. Bulletin of Kazan State University 2(24): 88-91.

3. Copenheaver, C., Grinter, E., Lorber,J., Neatrour,M., Spinney, M., 2002: A dendroecological and dendroclimatic analysis of Pinus virginiana and Pinus rigida at two slope positions in the Virginia Piedmont. Costanea 67(3): 302-315.

4. DeSiervo, M., Jules, E., Bost, D., De Stigter, E., Butz, R., 2018: Patterns and drivers of recent tree mortality in diverse conifer forests of the klamath mountains, California. Forest Science 64(4): 371-382.

5. Doyle, J.J., Doyle, J.L, 1987: A rapid DNA isolation procedure for small quantities of fresh leaf tissue. Phytochemical Bulletin 19: 11-15.

6. El-Kassaby, Y., Namkoong, G., 1995: Genetic diversity of forest tree plantations: consequences of domestication. In: Consequences of changes in biodiversity. IUFRO World Congress, Tampere, Finland 2: 218-228.

7. Feng, F., Han, S., Wang, H., 2006: Genetic diversity and genetic differentiation of natural Pinus koraiensis population. Journal of Forestry Research 17(1): 21-24.

8. Floran, V., Ganea, S., Sestras, R., Rosario, M., Gil, G., 2010: Genetic variability in populations of Scots pine from Romania and Sweden. Bulletin of University of Agricultural Sciences and Veterinary Medicine Cluj-Napoca. Horticulture 67(1): 481.

9. Gabdrakhimov, K., Khairetdinov, A., Sultanova, R., Konashova, S., Konovalov, V., Sabirzianov, I., Gabdelkhakov, A., Isianiulova, R., Martynova, M., Blonskaia, L., 2018: Reproduction of stable pine forests in the Southern Urals. Journal of Engineering and Applied Sciences 13(S8): 6494-6499.

10. Gil, M.R.G., Floran, V., Östlund, L., Gull, B.A., 2015: Genetic diversity and inbreeding in natural and managed populations of Scots pine. Tree genetics \& genomes 11(2): 28.

11. Grushetskaia, Z., Nikitinskaia, T., Kubrak, S., Dziuban, O., Kukhareva, L., Poliksenova, V., Titok, V., Lemesh, V. , Parfenov, V., Khotyleva, L., 2013: The use of the ISSR analysis for the study of intra-and interspecific genetic polymorphism of different taxons of higher plants. Bulletin of Bashkir State Agrarian University 1(3): 50-56.

12. Hong, Z., Fries, A., Wu, H.X., 2015: Age trend of heritability, genetic correlation, and efficiency of early selection for wood quality traits in Scots pine. Canadian Journal of Forest Research 45(7): 817-825.

13. Huiquan, Z., Hongjing, D., Dehuo, Hu, Yun, L., Yubao, H., 2015: Genotypic variation of Cunninghamia lanceolate revealed by phenotypic traits and SRAP markers. Dendrobiology 74: 85-94.

14. Hui-yu, L., Jing, J., Gui-frng, L., Xu-jun, M., Jing-Xiang, D., Shi-Jie, L., 2005: Genetic variation and division of Pinus sylvestris provenances by ISSR markers. Journal of Forest Research 16(3): 216-218.

15. Iarullin, R., Aipov, R., Gabitov, I., Linenko, A., Akchurin, S., Safin, R., Mudarisov, S., Khasanov, E., Rakhimov, Z., Rakhimov, Z., Masalimov, I., 2018: Adjustable driver of grain cleaning vibro-machine with vertical axis of eccentric masses rotation. Journal of Engineering and Applied Sciences 13: 6398-6406. 
16. Ivanovskaia, S., 2014: Evaluation of the gene resources of the Scots pine (Pinus sylvestris L.) in the plus stands of Belarus according to isoenzyme analysis. Proceedings of Bryansk State Technical University. Forestry 165(1): 130-134.

17. Kajba, D., Andric, I., 2019: Ex situ conservation. Case study Croatia. Forests of Southeast Europe under a Changing Climate 5: 259-269.

18. Nkongolo, K., Michael, P., Gratton, W., 2002: Identification and characterization of RAPD markers inferring genetic relationships among pine species 45(1): 51-58.

19. Novikov, P., Sheikina, O., 2012: The ISSR-analysis of the Scots pine trees (Pinus sylvestris) of different breeding categories. Scientific journal of Kuban State Agrarian University 82(8): 100-112.

20. Nowakowska, J., Zachara, T., Konecka, A., 2014: Genetic variability of Scots pine (Pinus sylvestris L.) and Norway spruce (Picea abies L. Karst.) natural regeneration compared with their maternal standards. Forest Research Papers 75(1): 47-54.

21. Porth, I., El-Kassaby, Y., 2014: Assessment of the genetic diversity in forest tree populations using molecular markers. Diversity 6(2): 283-295.

22. Prishnivskaia, I., Nechaev, I., Krasilnikov, V., Boronnikova, S., 2016: Molecular and genetic analysis of four populations of the Pinus silvestris L. in the East of the Russian Plain on the basis of polymorphism of ISSR markers. Bulletin of Orenburg State University 2(190): 88-93.

23. Provan, J., Soranzo, N., Wilson, N., McNicol, J., Forrest, G., Cottrell, J., Powell, W., 1998: Gene-pool variation in caledonian and European Scots pine (Pinus sylvestris L.) revealed by chloroplast simple-sequence repeats. Proceedings. Biological Sciences 265(1407): 697-705.

24. Raj, D., Govindaraju, D., Orians, C., 2006: Genetic variation among pitch pine Pinus rigida families from Walden Woods: heritability and path analysis of developmental variation of phenotypic traits. Rhodora 108(936): 356-369.

25. Redko, G., Merzlenko, M., Babich, N., Danilov, I., 2008: Forest crops and protective afforestation. Publishing center "Academy". Moscow, 400 pp.

26. Scalfi, M., Piotti, A., Rossi, M., Piovani, A., 2009: Genetic variability of Italian Southern Scots pine (Pinus sylvestris L.) populations: the rear edge of the range. European Journal of Forest Research 128(4): 377-386.

27. Seo, Y., Lee, Y., Lumbres, R., Pyo, J., Kim, R., Son, Y., 2013: Influence of stand age class on biomass expansion factor and allometric equations for Pinus rigida plantations in South Korea. Scandinavian Journal of Forest Research 28(6): 566-573.

28. Sheikina, O., 2014: Forest biotechnology. Study guide. Ministry of Education and Science of the Russian Federation, Federal State Budgetary Educational Institution of Higher Professional Education Povolzhskiy State Technological University. Ioshkar-Ola, 76 pp.

29. Shigapova, A., Shigapov, Z., 2009: Genetic diversity of the Scots pine populations Pinus sylvestris L. Bulletin of Orenburg State University 6: 445-447.

30. Sultanova, R., Gabdrakhimov, K., Khairetdinov, A., Konashova, S., Konovalov, V., Blonskaia, L., Sabirzianov, I., Martynova, M., Isianiulova, R., Gabdelkhakov, A., 2018: Evaluation of ecological potential of forests. Journal of Engineering and Applied Science 13(S8): 6590-6596.

31. Swamy, L., Drazen, E., Johnson, W., Bukoski, J., 2018: The future of tropical forests under the United Nations sustainable development goals. Journal of Sustainable Forestry 37(2): 221-256.

32. The Federal Target Program of the Forest Seed Production development for the period from 2009 to 2020, 2009. Federal Forestry Agency. Moscow, 86 pp. 
33. Tsarev, A., 2013: Forest breeding programs (in Russia and abroad). Monograph. Moscow State Forest University. Moscow, $164 \mathrm{pp}$.

34. Tsarev, A., Laur, N., 2006: Issues and problems of plus-breeding. Forest bulletin 9(3): 118-123.

35. Vidiakin, A., 2003: Problems of the conservation of genetic diversity of forest woody plants and some ways to solve them on the example of the Scots pine (Pinus sylvestris L.). Selection, genetic resources and conservation of the gene resources of forest woody plants (the Vavilov readings). Collection of scientific articles of Forest Institute of the National Academy of Sciences of Belarus. Gomel. Forest Institute of the National Academy of Sciences of Belarus 59(1): 98-101.

36. Vidiakin, A., 2008: Pine and spruce plus breeding: results and prospects of the development. Forestry information. In: Proceedings of scientific and technical conference on forestry 3(4): 33-38.

37. Vidiakin, A., Shigapov, I., 2010: Efficiency of woody plants plus breeding. The conifers of the boreal zone 27(1/2): 18-24.

38. Wieser, G., Gruber, A., Oberhuber, W., 2018: Growing season water balance of an inner alpine Scots pine (Pinus sylvestris L.) forest. IForest 11(4): 469-475.

39. Wójkiewicz, B., Cavers, S., Wachowiak, W., 2016: Current approaches and perspectives in population genetics of Scots pine (Pinus sylvestris L.). Forest Science 62(3): 343-354.

\author{
Elvira Khanova*, Vladimir Konovalov, Azat Timeryanov \\ Regina Isyanyulova, Dina Rafikova \\ Federal State Budgetary Educational Institution of Higher Education \\ Bashirir State Agrarian University \\ 50-Letiia Octiabria St., 34 \\ 45000 I UFA \\ Russia \\ *Corresponding author: elvirakhanova@rambler.ru
}

